Schulich School of Law, Dalhousie University

Schulich Law Scholars

Articles, Book Chapters, \& Blogs

Faculty Scholarship

2021

Human Rights and Transnational Organized Crime

Robert Currie

Sarah Douglas

Follow this and additional works at: https://digitalcommons.schulichlaw.dal.ca/scholarly_works

Part of the Criminal Law Commons, Human Rights Law Commons, and the Transnational Law Commons 


\title{
Human Rights and Transnational Organized Crime
}

\author{
Robert J. Currie and Sarah Douglas*
}

\section{Introduction}

Taking for granted that the phenomenal aspects of transnational organized crime (TOC) are explored in great detail in the other chapters of this handbook, the goal here is to bear down on two intertwined and fundamentally legal aspects: (1) the international legal regime around the suppression of TOC by use of the criminal law, and (2) the international system set up by states for the promotion and protection of human rights. In fact, as this chapter will demonstrate, these two bodies of international law are not only intertwined but symbiotic, each informing and informed by the other in substance, procedure, and direction.

Our choice to focus on legal topics here is deliberate, and derives from the very nature of the subject matter. "Human rights" means many things to many people, we suppose, but is fundamentally a legal concept describing the manner in which states (and sometimes their subunits) agree and are obliged to uphold, and refrain from unduly interfering with, certain fundamental entitlements and freedoms held by individuals. ${ }^{i}$ As these rights are ultimately creatures of international law, ${ }^{\text {ii }}$ we will emphasize international human rights law (Saunders and Currie 2019: 634-37). The "transnational" in "transnational organized crime" refers to the simple fact that this form of crime crosses state borders, and that the criminal enforcement response necessarily engages questions of public international law - most specifically, those issues covered by the body of law usually referred to as "transnational criminal law," which encompasses those norms through which states cooperate to suppress crimes of mutual interest (Boister 2018).

This chapter will scrutinize the points at which these two legal regimes intersect with and infuse each other. It will proceed in three sections. The first section will provide a brief overview of the international human rights law system, specifically tailored to ground the following parts. The second section will examine the means by which protection is given to the human rights of individuals who are targeted for criminal investigation and prosecution as a result of their alleged involvement in TOC (referred to for efficiency as "accused persons" or "the accused"). It will first briefly explain the means by which the accused's rights are protected (or meant to be so) in domestic criminal investigations, and then turn to the more complex questions around protecting accused's rights when they are targeted by inter-state cooperation mechanisms such as extradition.

The third and final section will examine the more cutting-edge issue of whether state obligations and activities around crime suppression can - and should - themselves promote and protect the human rights of individuals, in a proactive rather than reactive manner. This idea, lately referred to as "coercive human rights" (Lavrysen and Mavronicola 2020), will be explored through the lens of one of the more odious brands of TOC, human trafficking, and an examination of both the actual and prospective means by which crime control mechanisms can promote the human rights of victims. 


\section{The International Human Rights System}

While notions of human beings enjoying inherent fundamental or natural rights can be tracked back to antiquity, the modern scope of human rights law being discussed here can be safely "traced back to concerns with individual and constitutional rights which began to emerge in parliamentary action and philosophical writings from the late seventeenth century" (Harfield 2012). The atrocities of the Second World War firmed up ideas that had emerged from this background, specifically that it was not only necessary but desirable to limit the previously absolute sovereignty of states in order to prevent or provide redress for depredations perpetrated upon their own citizens, within their own borders. The Charter of the United Nations contained affirmative references to human rights as one of the primary purposes of the organization (and the new international order to which it gave rise), but the first clear statement of what was specifically aspired to emerged in 1948, with the Universal Declaration of Human Rights ('UDHR'). While not a binding treaty, the UDHR made strong aspirational declarations of entitlement to civil, political, economic, social, and cultural rights that essentially set the template for the emerging international human rights law regimes that followed.

Initial state resistance to such incursions on their sovereignty was eventually overcome and by 1966 the two treaties that, together with the UDHR, make up the "international bill of rights" were concluded: the International Covenant on Civil and Political Rights ('ICCPR') and the International Covenant on Economic, Social and Cultural Rights ('ICESCR'). These instruments have been supplemented by numerous other UN-sponsored treaties that put focus on particular rights, such as the 1979 Convention on the Elimination of All Forms of Discrimination Against Women ('CEDAW') and the 1984 Convention Against Torture and Other Cruel, Inhuman or Degrading Treatment ('UNCAT'). Regional human rights treaty systems have also emerged, including those under the European Convention on Human Rights ('ECHR') (1950), the American Convention on Human Rights ('AmCHR') (1969), the African Charter on Human and Peoples' Rights ('ACHPR')(1981), and the Arab Charter of Human Rights (ArCHR) (2004). iii

Of course, legal human rights norms are of little use when they are not enforceable against governments on the part of individuals. Enforcement essentially works in two ways. First, at the domestic level, states are required to "implement" or give effect to the human rights obligations which they have accepted under relevant treaties. Practically speaking, this means that they are meant both to guarantee the human rights to individuals and provide avenues of redress in cases where they do not. States approach this differently, in accordance with the way in which their domestic systems treat international law and with their own legal and constitutional arrangements. In Canada, for example, civil and political rights are constitutionalized by way of being enshrined in the Canadian Charter of Rights and Freedoms, which binds the federal and provincial governments to guarantee these rights and gives individuals the ability to obtain remedies from the courts for breaches (1984: s. 24). In the UK, by contrast, obligations are implemented via a statute, the Human Rights Act (1988). 
When states fail to comply with their international law obligations to guarantee human rights, then in principle they should be enforceable in two other ways: 1) proceedings brought by other states for violation of the treaty obligations; and 2) direct individual petition to a court or other enforcement body. The former option is not one that sees much traffic, but it is the latter that makes up some of the revolutionary aspects of international human rights law generally. Prior to the outset of this legal framework, international law was viewed as the preserve of states alone and involving only state-to-state obligations. Individuals were seen only as the objects of international law and not the subjects; they were acted upon but had no standing to act and were owed no duties by states. One of the main objectives of international human rights law is to allow individuals to pierce this domain and have the ability to bring governments to court in order to vindicate their rights.

Practically speaking, as a whole this is enforceability only in principle, for its robustness varies considerably from system to system. The apogee is the European system, in which individuals can bring their domestic cases to the European Court of Human Rights (ECtHR), its various chambers acting as ultimate courts of appeal. Notably, the rulings of this court are subject to direct application in the legal systems of the party states, meaning that states must adjust their laws and/or practices in order to comply with the court's interpretations of the ECHR. By contrast, states that are party to the ICCPR are subject to the UN Human Rights Committee, which can be directly petitioned by individuals; however, the Committee only issues "views" which are prima facie non-binding on the states against which proceedings are brought. The UN system also maintains expert bodies which monitor compliance with other instruments, such as the UN Torture Committee (UNCAT; Committee Against Torture) which can hear allegations that states have breached the UNCAT or bodies with still less "hard" authority like the UN Working Group on Arbitrary Detention, a body which investigates and issues reports on breaches of various treaty rights against arbitrary detention by government authorities (UNCAT; Working Group on Arbitrary Detention). To the extent that there is "case law" around the enforcement of human rights at the international level, then, it is the decisions that issue from these bodies.

As a final point, a useful explanatory device for understanding human rights is the "generation approach" first put forward by Karel Vasek and Philip Alston (1982). The first generation is civil and political rights, which are framed as prohibitions on state interference with individual liberties. The second generation is economic, social and cultural rights, which impose active duties on states to guarantee individuals' access to societal resources - for example, housing, education, employment. The third generation are collective rights, which encompass the ability of groups to claim entitlement to slightly more abstract rights such as self-determination, peace or a clean environment.

Most relevant for understanding the interactions of TOC and human rights are civil and political rights; they include procedural rights for the accused in domestic criminal processes and are in some ways implicated in inter-state cooperation between states, which are the foci of the first and second parts of the next section, respectively. However, the second generation rights have more recently been implicated in initiatives to protect victims of TOC, most notably survivors of human trafficking, which will be explored in the third section, below. 


\section{Protecting the Rights of the Accused in Organized Crime Cases}

\section{Domestic Cases}

States which are party to one or several human rights treaties are obligated to accord certain procedural rights to accused persons during the course of investigation, arrest, trial or sentencing in organized crime cases. The specific obligations accorded in a given state will, of course, depend on the treaties to which the state is party and the manner in which the state's domestic legal order protects the rights, as well as any binding inputs from a supra-national institution like the ECtHR, as noted above. The ICCPR, as the most universally-subscribed treaty, is a useful source of the most generally-accepted procedural rights:

Article 6: the right against arbitrary imposition of the death penalty

Article 7: the right against torture or cruel, inhuman or degrading treatment

Article 9: the right to liberty and security of person, which protects against arbitrary arrest and detention, and provides entitlement to: prompt notification of reasons and charge upon arrest; habeas corpus; trial within a reasonable time; an opportunity for judicial release

Article 14 provides a suite of criminal procedural rights, including:

Equality before the courts, and a fair and public hearing before a competent, independent and impartial tribunal established by law

The right to be presumed innocent until proven guilty

Prompt information on the nature of the charge

Adequate time/facilities to prepare a defence and the right to consultation with counsel of choosing

Trial without undue delay

Right to a trial in his presence, with legal assistance

To examine witnesses against the accused and the opportunity to call their own

Free assistance of an interpreter

Right not to be compelled to testify against oneself or to confess guilt

Right to review of a conviction or sentence before a higher court

Right against double jeopardy

Article 15: the right against retroactive application of criminal law

Article 17: the right against arbitrary or unlawful interference with privacy, family home or correspondence 
The ways in which these procedural rights are implicated in TOC cases are, of course, as numerous as the states which conduct them, and space does not permit any serious exploration of that here. It is worth noting, however, that the specifics of the transnational criminal law regimes dedicated to suppressing TOC may very well give rise to interesting domestic applications of the prosecuting state's human rights obligations. For example, one of the innovative substantive provisions of the United Nations Convention on Transnational Organized Crime ('UNTOC')(2000) was Article 5, which obliges states to criminalize participation in an "organized crime group." Article 15 of the ICCPR requires that states define crimes "with sufficient provision to regulate their conduct". iv In Canada, the provisions brought in by the government to implement the UNTOC participation offence were challenged in several cases as being too vague to allow individuals to know in advance what conduct was proscribed, and thus in violation of section 7 of the Canadian Charter of Rights and Freedoms, which gives effect to the relevant aspect of Article 15 of the ICCPR. The courts, drawing on the previous section 7 jurisprudence, accepted the proposition that precision was required, but (drawing on the UNTOC itself as an interpretive guide) held that the formulation of the offences was sufficiently precise ( $R v$ Terezakis, 2007; $R v$ Lindsay, 2009).

As noted above, accused individuals in TOC cases have some ability to seek vindication of their rights at the international level, before the enforcement body of the relevant treaty regime(s) to which their state is party. There are a number of instances that have examined breaches of civil rights, in particular, in these cases. For example, in Orejuela v Colombia (2002), the petitioner was alleged to be the head of the Cali cartel, and successfully argued to the UN Human Rights Committee that his right to a fair trial under Article 14 of the ICCPR had been violated by Colombia. By contrast, in Podeschi v San Marino (2017), the petitioner was unsuccessful in arguing that various rights under Articles 3, 4 and 5 of the ECHR had been breached during his detention and trial on various money laundering charges.

\section{Inter-State Cooperation}

A central feature of the transnational criminal law regime that seeks the suppression of TOC is the treaty mechanisms that provide for cooperation between states, most notably along the lines of extradition, mutual legal assistance and policing cooperation. The manner in which the human rights of the accused are, can or should be protected in this space, however, has been problematic for many decades. The late Professor Cherif Bassiouni (1974: 427, 429) noted that the eagerness of states to enter into arrangements under which they could cooperate to suppress crime was completely disconnected from the extension of any procedural protections for the individuals being investigated and prosecuted. More recent surveys of state practice indicate that while some progress has been made, Bassiouni's observation is still extant, particularly outside the more robustly protective regime under the ECHR (Currie 2015).

This is best understood as a problem of lack of states' political will. The policy goal behind the transnational criminal law regime has been, unsurprisingly, the suppression of crime, and states 
have resisted injecting human rights protections into the system. This can first be seen in the suppression treaties themselves. Professor Boister (2002) noted the hollowness of the Vienna Narcotics Convention (1988) with regard to any human rights protections, beyond vague references to protections that might (or might not) exist within the constitutional order of the party states. The UNTOC saw only slight improvements on this, with rather watery references to "due regard to the rights of the defence" (UNTOC 2000: arts 11(3), 18, 24(2), 25(3)) and, in the extradition provisions specifically, an obligation to provide "fair treatment" in keeping with "all the rights and guarantees provided by the domestic law of the State party in the territory of which the person is present." (UNTOC 2000: art 16(3)). Currie (2015: 34) has recently noted the overall moribund level of protection in the transnational suppression treaties generally, which at their highest oblige states to adhere to their already-existing international human rights law obligations when engaged in inter-state criminal cooperation - thus truly providing no additional protection at all.

The same lack of political will can be seen in the areas of extradition ${ }^{\mathrm{v}}$ and mutual legal assistance, ${ }^{\mathrm{vi}}$ which are conducted by way of primarily bilateral and occasionally multilateral treaty between cooperating states. While there are encouragements in this regard stemming from the $\mathrm{UN},{ }^{\text {vii }}$ generalized and hard norms are hard to come by. Certain treaty-based human rights protections have infiltrated the landscape, but only with regard to the most serious human rights violations. ${ }^{\text {viii }}$

The main challenge has been convincing states to acknowledge that, by using criminal cooperation to facilitate human rights violations by or in a state requesting cooperation, the requested state's human rights obligations are engaged. To the extent this has taken place, it has been when states are dragged before either their own domestic courts or international courts/adjudicatory bodies. The watershed moment in this regard is usually held to be the ECtHR's 1989 decision in Soering v United Kingdom (1989), ${ }^{\text {ix }}$ where the court held that by extraditing the accused to face cruel and unusual treatment via being placed on death row in the US, it would violate its own obligation under Article 3 of the ECHR not to impose "inhuman or degrading treatment or punishment." That is to say, it is a breach of international human rights law for a state not only to engage in human rights violations, but to provide assistance in criminal matters to another state which does or is reasonably expected to do so.

This "Soering principle" (Currie 2000) has inspired similar findings in the decades since its inception. The ECtHR itself has a relatively well-developed jurisprudence on cooperation in criminal matters, as might be expected. Outside that space, developments have been uneven. The UN Human Rights Committee has held that states can breach the ICCPR for extraditing accused individuals to face a death sentence or cruel and unusual punishment, ${ }^{\mathrm{x}}$ as has the UN Torture Committee (Boily v Canada 2011), but of course neither of these fora can impose obligatory measures on the party state. Domestic courts have also followed the lead of Soering, such as the Supreme Court of Canada in United States v Burns (2001), where extradition to face the death penalty was proscribed, and the recent decision of the United Kingdom Supreme Court in Elgizouli $v$ Secretary of State for the Home Department (2020), which held that providing mutual legal assistance in a death penalty case breached the human rights of the accused. 
In terms of solid and globally-binding norms, however, the landscape is fairly modest. In 2013, Professor Satterthwaite, based on a wide-ranging study of state practice, provided a fairly defensible account that is still current. She opined that states are obliged as a matter of international human rights law to "refrain from transferring any individual to the custody of a state where he is at a real risk of: torture or ill-treatment; persecution; enforced disappearance; and arbitrary deprivation of life" (Satterthwaite 2013: 615). One also encounters evidence of states - usually wealthier, developed states - taking account of problems with their cooperation partners by resisting cooperation (Currie 2019), or extracting assurances of rights-compliant treatment in specific cases (Johnston 2011: 1). Beyond this, developments are uneven and the preferred resort is to discretion on the part of requested states. As Currie observed, "While there is a sense of forward motion, it is slow and its direction uncertain" (Currie 2015: 40).

\section{Respecting Human Rights of Victims in Crime Suppression}

As discussed thus far, states have duties to respect, protect and fulfill human rights (United Nations Office on Drugs and Crime ('UNODC') (2012). ${ }^{\mathrm{x}}$ To the extent that the transnational legal regime dedicated to suppressing TOC takes these duties on board, it has traditionally been regarding the procedural rights of the accused. However, more recently, greater attention is paid to the manner in which states can be obliged to use the criminal law to actively protect human rights, particularly those of victims. We will examine the regime around the suppression of human trafficking, specifically under the UNTOC, as a case study.

\section{a. Interaction between victims' human rights and crime suppression}

\section{i. International Human Rights Law as a supplement to Transnational Criminal Law}

International human rights law is an intimate supplement to transnational criminal law. The effective prevention and suppression of TOC requires an holistic approach by states that employs both criminal justice responses and human rights standards (Obokata 2019: 3). Neither UNTOC, its protocols, nor regional instruments fully meet all human rights standards; therefore, international human rights law can fill in these gaps to realize victims' human rights (Obokata 2006a: 164). Under transnational law supplemented by international human rights law, states have a duty to investigate, prosecute and punish offenders; prevent the criminal activity; and protect victims (Obokata 2019: 3).

To start, the basis for a successful strategy against TOC is a "well-functioning, efficient, fair, effective and humane criminal justice system" (UN Commission on Crime Prevention and Criminal Justice Report ['CCPCJ Report'] 2018). However, several human rights are engaged in transnational organized crimes, not just those directly related to criminal justice responses. These include fundamental rights to life, liberty and security of person, as well as prohibitions on slavery, forced labour, and other inhuman and degrading treatment (ICCPR 1966: arts 6(1), 7, 8, 9). ${ }^{\text {ii }}$ Rights to health and culture may be engaged (ICESR 1966: arts 8, 12, 15). ${ }^{\text {iii }}$ For this reason, crime prevention strategies should employ gender and youth perspectives, and be mainstreamed throughout states' national policies, spanning education, socioeconomic opportunity, information 
and communications technology and public safety, and others, to prevent social marginalization and exclusion, reducing the risk of individuals becoming offenders and victims (CCPCJ Report 2018: Recommendation 6). Suppression of TOC is directly linked with broader obligations found within international human rights jurisprudence.

\section{ii. States' obligations respecting serious violations of human rights}

States have a duty to prevent victims of serious crimes and they are required to effectively respond to gross violations of individual rights. ${ }^{\text {xiv }}$ Strengthened by existing transnational criminal law instruments, this duty requires states to take reasonable steps to prevent human rights violations, and investigate and prosecute serious crimes committed within its jurisdiction, punishing violations of human rights committed by private actors (Velasquez-Rodriguez $v$ Honduras 1988). Effective criminal investigation is a duty owed by states to victims of serious crimes (Case of Trufin v Romania 2009), which must be conducted within a reasonable time (Manuel Garcia Franco $v$ Ecuador 1997). These enforcement obligations against non-state actors apply to perpetrators of organized crime (Obokata 2017: 53).

Human trafficking is considered a serious violation of human rights. Trafficking is "found at the intersection of three branches of international law: international human rights law, international criminal law and transnational criminal law (Obokata 2006a: 165-6)." The following case study explores states' obligations to prevent and suppress human trafficking, ideally through an holistic approach that addresses both its causes and consequences (Obokata 2006a: 161).

\section{b. Human rights in the context of human trafficking}

\section{i. Human trafficking and related exploitation}

Human trafficking ranks as one of the most serious crimes impacting the entire international community (Obokata 2005a: 445). Approximately 40.3 million people are trafficked worldwide through forced labour, marriage, and sexual exploitation (International Labour Organization 2017: 9). The most comprehensive definition of human trafficking arises from the UNTOC Protocol to Prevent, Suppress and Punish Trafficking in Persons, especially Women and Children (the "Human Trafficking Protocol") (Human Trafficking Protocol 2000), ${ }^{\mathrm{xv}}$ recognized as the "leading international law instrument on human trafficking" (Currie and Rikhof 2020: 388). Human trafficking is defined as the:

recruitment, transportation, transfer, harbouring or receipt of persons, by means of the threat or use of force or other forms of coercion, of abduction, of fraud, of deception, of the abuse of power or of a position of vulnerability or of the giving or receiving of payments or benefits to achieve the consent of a person having control over another person, for the purpose of exploitation. Exploitation shall include, at a minimum, the exploitation of the prostitution of others or other forms of sexual exploitation, forced labour or services, slavery or practices similar to slavery, servitude or the removal of organs (Human Trafficking Protocol 2000: art 3(a)). 
This definition has since been interpreted to include forced marriage and forced begging (Jha 2018: 240). Under this definition, it is not relevant whether a victim consented to any intended exploitation if any of the means above were used to carry it out (Human Trafficking Protocol 2000: art 3(b)). Even if the means above were not used, any child recruited, transported, transferred, harboured or received for the purpose of exploitation is considered trafficked (Human Trafficking Protocol 2000: art 3(c)). . $^{\mathrm{vi}}$

The crime of human trafficking is made up of three elements under this definition. There must exist: (a) the action of recruiting or transporting a person; (b) "a means used to carry out the action," such as threat or use of force, coercion or abduction; and (c) a prohibited purpose for the exploitation (Currie and Rikhof 2020: 388). The UNODC Model law against Trafficking in Persons "understands 'exploitation' as 'conditions of work inconsistent with human dignity" (Noortmann and Sedman 2016: 410).

Human trafficking is well acknowledged as a human rights issue, particularly as a grave violation of human rights (First Conference of Parties to UNTOC 2004). Trafficking is a form of violence against women and girls (Vienna Declaration and Programme of Action 1993: para 13; Obokata 2006b: 33), and is considered a contemporary form of slavery (Obokata 2006b: 18). The involvement of organized criminal groups "marks the transition from the traditional form of slavery to the modern trafficking of human beings" (Obokata 2006b: 30) Early trafficking conventions primarily addressed its impact on white populations, but current "racial demographics of the crime refute [those] antiquated conceptions" (Fish 2017: 534).

In the TOC realm, human trafficking is considered a low risk undertaking for perpetrators, and is highly profitable (Obokata 2006b: 27). Collectively, the International Labour Organization estimates trafficking is a $\$ 150$ billion industry, $\$ 99$ billion of which is generated by sexual exploitation (International Labour Organization 2014: 13, 15). According to the UNODC Global Report on Trafficking in Persons (2018), sexual exploitation continues to be the most detected form of trafficking, amounting to nearly 60 percent (of which victims are 68 percent women and 23 percent girls) (2018: 29, 33 fig 21). Most trafficked men are subjected to forced labour (2018: 28 fig 16). An increase of nearly 40 percent of detected trafficking cases between 2011 and 2016 is due in part to better detection and reporting standards (2018: 28, 29 fig 16, 21); ${ }^{\text {xvii }}$ however, these estimates are likely too modest given the crime's clandestine nature and a lack of states' diligence in suppressing it (Currie and Rikhof 2020: 387).

ii. Human rights obligations

The issue of human trafficking illuminates the balance between states' obligations respecting gross violations of human rights, and their efforts to suppress transnational crime. The three key obligations - to investigate and prosecute offenders, and to prevent as well as protect victimsarise from specific suppression conventions, regional agreements, and complementary human rights instruments.

The Human Trafficking Protocol, the primary suppression convention for this overview, aims to establish a universal comprehensive approach to effectively prevent trafficking in persons, particularly of women and children (Human Trafficking Protocol 2000: preamble). Similar to conventions responding to other TOC, this approach requires preventive and prosecutorial 
measures (2000: preamble) and cooperation between states in meeting their obligations to prevent trafficking and to protect and assist victims (2000: preamble, art 2).

A number of other regional conventions also exist to suppress the crime of human trafficking. These include: the Council of Europe Convention on Action against Trafficking in Human Beings ('Council of Europe Convention'(2005: art 1); ${ }^{\text {xviii }}$ the South Asian Association for Regional Cooperation Convention on Preventing and Combatting Trafficking in Women and Children for Prostitution ('SAARC Convention')(2002: art II); ${ }^{\text {xix }}$ the Inter-American Convention on International Traffic of Minors ('Inter-American Convention') (1994: art 1); ${ }^{x x}$ and the Arab Convention on Combating Transnational Organized Crime (2012: arts 11,12). ${ }^{x i}$ In addition, forced and child marriage, which can be considered a form of slavery, are explicitly prohibited under the Supplementary Convention on the Abolition of Slavery, the Slave Trade, and Institutions and Practices Similar to Slavery" (2017: 18).

Obligations respecting trafficking victims also arise in other human rights instruments. The human rights framework supplements the transnational criminal law response, particularly because factors such as poverty and unemployment must be alleviated in law and policy to effectively suppress the crime (Obokata 2006c: 79). Suppression must also address important issues including violence against women, discrimination against minorities, and law enforcement practices, all absent from the Human Trafficking Protocol and regional suppression conventions (Obokata 2006a: 164).

As noted above, the human rights framework is largely rooted in the ICCPR (1966) and ICESCR (1966). The ICCPR prohibits forced labour, slavery and servitude, and a state must ensure that all individuals within its jurisdiction can enjoy this right (and the others enshrined within the ICCPR, a standard interpreted by the UN Human Rights Committee) (UN Human Rights Committee 1981). Further, the ICESCR upholds the right to work and the "enjoyment of just and favourable conditions of work" (1966: arts 6,7) as well as protecting children from economic exploitation (1996: art 10(3)).

Other relevant universal conventions include CEDAW (1979), the Convention on the Rights of the Child ('CRC') (1989: arts 3(1), 3(2), 6(2) and 11(1)), ${ }^{x i i}$ and the Optional Protocol to the Convention on the Rights of the Child on the sale of children, child prostitution and child pornography ('CRC OPSC') (2000). Lastly, the Worst Forms of Child Labour Convention (1999) asserts "the use, procuring or offering of a child for prostitution" as one of the worst forms of child labour, requiring states to take immediate, effective measures to prohibit it (1999: arts 3(a), 3(b) and 6).

Regional human rights instruments that contain specific provisions prohibiting trafficking in persons, child trafficking, or an analogous form of slavery, include the African Charter on Human and Peoples' Rights (ACHPR 1981: art 5); ${ }^{x i i i}$ the American Convention on Human Rights (AmCHR 1969: art. 6); ${ }^{\text {xxiv }}$ the Arab Charter of Human Rights (ArCHR 2004: art 10); ${ }^{x x v}$ and the European Charter of Fundamental Rights (ECFR 2012: art 5). ${ }^{\text {xxi }}$

The protection of victims' rights is also supported by other soft law, including the Recommended Principles and Guidelines on Human Rights and Human Trafficking, which affirms "States have a responsibility under international law to act with due diligence to prevent trafficking, to investigate and prosecute traffickers and to assist and protect trafficked persons"(UN High Commissioner for Human Rights 2002: 3 at para 2). Failing to correctly identify a trafficked person 
will likely result in further denial of their rights; therefore, states are "under an obligation to ensure that such identification can and does take place" (Jha 2018: 243).

The human rights of trafficked persons and the uniquely gendered nature of this crimedisproportionately impacting women and girls-should also be considered in light of the Sustainable Development Goals (SDGs) outlined in the UN 2030 Agenda for Sustainable Development (2015). Specifically, the SDGs task states with taking immediate action "to eradicate forced labour, end modern slavery and human trafficking and secure the prohibition and elimination of the worst forms of child labour" (SDG 2015: target 8.7); eliminating "all forms of violence against women and girls in the public and private spheres," including trafficking and sexual exploitation (SDG 2015: target 5.2); eradicating abuse, exploitation, trafficking, and all forms of violence and torture against children; and collecting, evaluating and disaggregating victim data (SDG 2015: target 16.2).

Together, this constellation of suppression conventions and human rights instruments establishes an international legal framework responding to the perverse issue of trafficking in persons.

\section{Investigation and prosecution}

These conventions and instruments specifically respond to the obligation to investigate, prosecute and punish perpetrators of gross violations of human rights, including human trafficking (Human Trafficking Protocol 2000: art 3 para 4, 5).

Article 5 of the Human Trafficking Protocol requires states parties to adopt legislation and other necessary measures to establish criminal offences for the intentional trafficking of persons, the attempt to traffic in persons, being an accomplice to trafficking, or organizing others for these purposes (2000: art 5). Further, the Protocol supplements UNTOC; therefore, UNTOC's provisions respecting criminalization, investigation, co-operation and prosecution, also apply to the Protocol (2000: art 1).

The SAARC Convention provides for the "widest measure of mutual legal assistance in respect of investigations" or other procedures (2002: art VI), and contains its own provisions on extradition and prosecution (2002: art VII). The Inter-American Convention similarly requires states parties to institute a system dedicated to prevention and punishment through mutual legal assistance, by adopting relevant administrative and legal provisions (1994: art 1(b)). International human rights law also raises obligations around criminalization, investigation and co-operation; for instance, with respect to children (CRC OPSC 2000: arts 6, 7, and 10), and the treatment of all victims (UN Res 64/293 2010: para 27). States' obligations to cooperate on crime suppression, across these like-minded conventions, have yielded tangible results. ${ }^{\text {xxvii }}$

As a gross violation of human rights, states must also provide remedy and reparation to trafficking victims. Under the Basic Principles and Guidelines on the Right to a Remedy and Reparation for Victims of Gross Violations of International Human Rights Law and Serious Violations of International Humanitarian Law ('Resolution 60/147'), states must establish systematic and thorough domestic mechanisms for remedy and reparation (2005). Under Resolution 60/147, these rights include: "(a) equal and effective access to justice; (b) adequate, effective and prompt reparation for harm suffered; and (c) access to relevant information concerning violations and reparation mechanisms" (2005: art VII para 11). Under Article IX, para 15: 
Reparation should be proportional to the gravity of the violations and the harm suffered. In accordance with its domestic laws and international legal obligations, a State shall provide reparation to victims for acts or omissions which can be attributed to the State and constitute gross violations of international human rights law or serious violations of international humanitarian law.

Resolution 60/147 reaffirms these rights found elsewhere, including the ACHPR (1981: art 7), AmCHR (1969: art 25), the European Convention for the Protection of Human Rights and Fundamental Freedoms (1950: art 13), and the ArCHR (2004: art 23). ${ }^{\text {xxiii }}$

Asset recovery and confiscation of criminal proceeds is part of states' investigation and prosecution obligations. In addition to this duty under UNTOC Article 12, these measures can serve to restore the property rights of victims and support 'the devotion of States' maximum available resources to the fulfilment of economic, social and cultural rights under Article 2(1) of the ICESCR," by suppressing crimes like corruption, tax evasion, and money laundering (Obokata 2019: 16). The Special Rapporteur on Human Trafficking has stressed the need for effective asset recovery, an obligation that should apply to all organized crime suppression (Obokata 2019: 16).

\section{Prevention}

Many factors make people vulnerable to human trafficking. In addition to economic and social risk factors such as poverty, homelessness, and involvement in child welfare systems, "political upheaval, armed conflict, and natural disaster can increase [one's] risk for human trafficking" (Fish 2017: 534). Indeed, "refugees and migrants in large movements are at greater risk of being trafficked and of being subjected to forced labour" (UN Res 72/1 2017: para 18). Under transnational criminal law and international human rights law, states must work to alleviate these vulnerabilities.

Article 9 of the Human Trafficking Protocol requires states parties to establish comprehensive prevention policies, programming and other measures (2000: art 9(1)), which may be established in cooperation with civil society (2000: art 9(3)). States may undertake research, public awareness campaigns and economic initiatives toward prevention (2000: art 9(2)). This obligation also includes states' responsibilities to discourage demand that leads to trafficking through legislative, social or cultural measures (2000: art 9(5)); this is an important factor in curbing organized crime as a "market-driven force" (McSherry and Cullen 2007: 208). Additionally, states' prevention policies and programs should also protect victims from re-victimization (2000: art 9(1)(b)).

With respect to prevention, any strategy should "pay sufficient attention to the supply-demand dynamics" of the crime (Obokata 2019: 28). The Council of Europe Convention, for instance, lays out measures to discourage demand, including targeted information and public awareness campaigns, educational programs for girls and boys, and research on best practices and strategies (2005: art 6). Prevention measures of the SAARC Convention extend to training and sensitization of authorities, the establishment of a regional task force, information exchange, public awareness campaigns and focusing development efforts on vulnerable areas (2002: art VIII). 
At international human rights law, states must take measures, exercising due diligence, to prevent trafficking by working to alleviate poverty, general inequality and humanitarian crises (UN Res 72/1 2017: para 3), and by countering recruitment methods (for instance, intervening in the use of information and communications technology to carry out criminal activities and facilitate trafficking) (CCPCJ Report 2018: UN Res 27/2, 27/3). ${ }^{\text {xxix }}$ States can alleviate poverty, for instance, by increasing access to education and training or other gainful opportunities (Obokata 2019: 31). Reducing poverty as a root cause of trafficking also means that both 'destination' states and those considered 'transit' states have a duty to assist states where trafficking originates (Obokata 2006a: 163).

CEDAW requires states parties to take all appropriate measures to suppress all forms of trafficking and exploitation of women (1979: art 6); end discrimination in employment by promoting gender equality and safety, and protecting women's free choice of occupation (1979: art 11); and, echoing the ICCPR (1966: art 23(3)), protect the need for marriage to be based on free and full consent (CEDAW 1979: art 16(1)(b)). Under the CRC, states must "take all appropriate legislative, administrative, social and educational measures to protect the child" from all forms of exploitation (1989: art 19), including sexual (1989: art 34) and economic exploitation, and work that is hazardous or harmful to the child's health or development (1989: art 32). Moreover, with particular attention to children who are especially vulnerable, parties to OPSC must adopt similar measures to prevent children's exploitation (CRC OPSC 2000: art 9).

\section{Protection of victims}

"Given that human trafficking is a gross violation of the rights of trafficked victims, their protection should be at the centre of any action against this crime" (Obokata 2015: 177).

Under the Human Trafficking Protocol, states are obligated to protect and assist trafficking victims, with full respect for their human rights (2000: art 2(b)). ${ }^{\mathrm{xxx}}$ Article 6 outlines several commitments states parties must undertake to support and protect victims with regard for their physical safety; physical, psychological and social recovery; and their privacy (including in legal proceedings). States must also take into account the special needs of victims, particularly children (2000: art 6). States should consider implementing measures providing for recovery, in some cases in cooperation with civil society, including through "(a) appropriate housing; (b) counselling and information [including legal rights in a language the victim understands]; (c) medical, psychological and material assistance; and (d) employment, educational and training opportunities" (2000 art 6(3)). In meeting these obligations, states should "secure effective witness protection [and] free access to interpreters and legal advice. States also have an obligation to protect the health of those trafficked, regardless of their legal status, by securing equal access to health facilities" (Obokata 2006a: 157).

The non-removal of victims, or their safe repatriation to their country of origin (ideally, voluntarily), are also measures states must undertake (Human Trafficking Protocol 2000: art 8(2)). These additional obligations include adopting legislative or other measures that permit victims to remain in a state's territory, temporarily or permanently (for instance, by issuing temporary visa 
permits), giving "appropriate consideration to humanitarian and compassionate factors" (2000: art 7).

Under the Human Trafficking Protocol, states' authorities (for example, law enforcement and immigration) are also obliged to cooperate, in accordance with their domestic law, through information exchange to better identify victims and the means or methods of organized criminal groups (2000: art 10(1)). States may also provide or strengthen such authorities' training on prevention, which should consider "human rights and child- and gender-sensitive issues" (2000: art 10(2)).

In some contexts, these protections are not always afforded unconditionally, and some criticize this approach as falling short of honouring human rights obligations. In some jurisdictions, assistance is conditional on victims' cooperation in investigations or subsequent prosecutions. To some scholars, this requirement may have dangerous consequences. "The only hard obligation ('shall ensure') relates to assistance during criminal investigation and proceedings. This enhances the perception that victims are used as tools for criminal justice and undermines the key aim of the [Human Trafficking Protocol]" (Obokata 2015: 178). Additionally, victims' protection should not cease once prosecution concludes; instead, protection should continue if a victim has genuine fear of retribution by the organized criminal group, social exclusion if they return to their country of origin, or when the potential for re-trafficking is high (Jha 2018: 238). In these cases, it may not be in victims' interests to assist a prosecution (Jha 2018: 238).

The Council of Europe Convention actually builds in a 30 day 'recovery and reflection period' once a victim has been identified on reasonable grounds, within which time a state party may not enforce any expulsion of the individual, and within which time the victim can hopefully "escape the influence of traffickers and/or to take an informed decision on cooperating with the competent authorities." (2005 art 13). This Convention largely reflects much of the Protocol's obligations respecting victims' assistance in terms of accommodation, access to medical treatment, access to legal counsel, and translation services (2005: art 12). This Convention also provides specific measures for unaccompanied children, including legal representation acting in the best interests of the child, establishing the child's identity and nationality, and if appropriate, locating the child's family (2005: art 10). The SAARC Convention likewise promotes the care, rehabilitation and repatriation of victims (2002: art IX), and the Inter-American Convention implores states to undertake to ensure minors' protection and their prompt return to their country of origin, if in their best interests (1994 art 1(a), (c)).

Positive obligations to protect and assist victims are also promoted within international human rights instruments. This is particularly important for asserting the obligation to protect because international human rights law promotes a victim-centred approach (Obokata 2019: 18). Generally, the obligation to protect is "established from a duty to secure, ensure or restore rights, and to provide remedies;" and the actual protection measures required are informed by the degree of victimization, which crimes were committed, and which rights have been affected (Obokata 2019: 18, 19).

With respect to child victims, the best interests of the child are the primary consideration in "all actions concerning children, whether undertaken by public or private social welfare institutions, 
courts of law, administrative authorities or legislative bodies" (CRC 1989: art 3(1)). States should ensure appropriate assistance is given to child victims for "their full social reintegration and their full physical and psychological recovery," (CRC OPSC 2000: art 9(3)) within an environment that fosters the child's health, self-respect and dignity (CRC 1989: art 39).

With respect to protecting the right to life, states must take measures to protect individuals within their jurisdiction whose lives are at risk from the criminal acts of others (Obokata 2019: 19). This can be met by establishing and maintaining "criminal prohibitions and sanctions on all forms of arbitrary deprivation of life resulting from transnational organised crime" (Obokata 2019: 19). Further, the UN Global Plan of Action Combatting Trafficking in Persons requires States to support the re-integration of victims into their communities (UN Res 64/293 2010: para 26). Unfortunately, where victims "are often seen as a threat to internal security because of their connection with criminal activities and organisations [...] such measures as detention and deportation are frequently taken" (Obokata 2006a: 153).

\section{Breaches of these obligations}

States can be held accountable if they fail to effectively implement a core human rights obligation (Obokata 2010: 131). For instance, in Siliadin v. France (2006), the ECtHR held that France had breached Article 4 of the ECHR, by failing to enact criminal provisions to prohibit slavery, servitude and forced labour (Obokata 2010: 131, fn 68).

There may also be potential attribution to states that breach their obligation of due diligence (Noortmann and Sedman 2016: 417). A state may incur international responsibility for acts by private individuals based on the actions or omissions of a state's organs that "are guilty of not having done everything within their power to prevent the injurious act of the private individual or to punish it suitably if it has occurred despite everything" (Jha 2018: 247). In Chowdury and Others v. Greece (2017), for instance, the ECtHR held that Greece failed in its obligations to prevent human trafficking, protect victims, and effectively investigate offences involving fortytwo Bangladeshi nationals working in forced labour, in difficult physical conditions, and without work permits. ${ }^{\text {xxi }}$

In implementing the obligation to investigate offences, for instance, anti-trafficking statutes may include a specific provisions promoting research and monitoring the role of public corruption plays in trafficking response; where statutes prohibiting trafficking do not include anti-corruption provisions, or where a state "does not investigate the conduct of questionable public officials, the state agencies may be held liable under international law on the ground of state responsibility" (Jha 2018: 250).

\section{iii. Related issues to consider}

The challenges and obligations stemming from and contributing to the complex issue of human trafficking also raise a number of other noteworthy points of academic discourse warranting further consideration. Among these are concepts regarding the role of global governance in combatting the problem, and whether the crime of human trafficking should be classified as an international crime (e.g. a crime against humanity) and elevated to the status of jus cogens. 
Tom Obokata calls for a global governance approach to "to promote an effective response" to trafficking (2010: 121), given states are not the only actors doing anti-trafficking work. Obokata argues this approach centres on an "extensive disaggregation of authority" (2010: 124), and tasks civil society and other international non-state actors with prevention and protection work, as well as the training of law-enforcement, immigration and other relevant officials (2010: 129). Protection of victims and their cooperation in investigations require state and community organization support (2010: 127), particularly for a trauma-informed approach to victims' recovery (United States Department of State 2018: 24), and respect for victims' agency (United States Department of State 2019: 24, 25). Further, states must work with other actors to address 'pull' factors, like demand, and 'push' factors, like gender discrimination, poverty and humanitarian crises (Obokata 2010: 128). Obokata argues that international human rights law combines the strengths of transnational criminal law and international criminal law; therefore, "international human rights law has the strongest potential to facilitate governance over trafficking at the global level compared to other branches of international law" (2010: 135).

Elsewhere, Obokata argues for trafficking in persons to be considered a crime against humanity, particularly for the ability to prosecute individuals before the International Criminal Court" (2010: 131, 133). ${ }^{\text {xxxi }}$ Part of this approach may include considering transnational criminal organizations as being entities owing the same duties to uphold human rights, and to which violations they can be attributable. ${ }^{\text {xxiii }}$ Under this model, "indirect enforcement of human rights norms and principles against non-State actors becomes possible" (Obokata 2005a: 456).

This case study of human rights obligations owed by states in this context is incomplete without two important acknowledgments. The first is that many challenges and obligations around human trafficking overlap and intersect with other activities rife with human rights abuses, especially human smuggling. The second is the growing practice of states and international organizations building and enforcing accountability mechanisms targeting internal practices of private sector and civil society actors, since supply chains "have a very important role in identifying human trafficking cases" (Jha 2018: 249).

\section{Shared human rights concerns with human smuggling}

First, many scholars and international actors advocate for a better understanding of the shared human rights concerns and links between human trafficking and human smuggling. Indeed, they are both "fluid and interrelated phenomena, and generally exist on [an irregular migration] continuum," (Lelliot 2017: 239) their most obvious commonality in this context being their crossborder nature.

Human smuggling is the fastest growing criminal market (Lelliot 2017: 239). Displacement, due to climate change or conflict, for example, is a common and serious catalyst for massive migration

and demand for smugglers. ${ }^{\text {xxxiv }}$ Europe has seen a recent sharp increase in child trafficking, for instance, owing to the current global migrant crisis (UN Doc A/72/164 2017: para 21):

Factors contributing to the sexual exploitation of children on the move include their lack of financial resources, the failure of child protection and welfare systems to act as a safety net, the prolonged exposure to inhumane 
living conditions and a protracted and overly burdensome path to residence status (UN Doc A/72/164 2017: para 33).

Children's dependence and unique vulnerabilities also make them particularly susceptible to trafficking (Lelliot 2017: 239).

While trafficking naturally attracts a human rights lens given the largely involuntary transport and subsequent exploitation of victims, human smuggling does not if it is viewed "merely as facilitation of illegal migration" (Obokata 2005b: 395). In truth, however, smuggling equally raises the issue: it "can be both the cause and consequence of human rights violations," (Obokata 2005b: 395) particularly in terms of abuse and exploitation. Migration, which precipitates the demand for smuggling, and trafficking stem from similar root causes, such as gender and racial discrimination and unequal access to economic opportunity (Obokata 2005b: 399-400). Further, smuggled persons experience degrading treatment during their journey due to harsh conditions of their travel, abandonment, or physical and sexual violence (Obokata 2005b: 400). Generally, labour migrants - particularly women - experience numerous issues in the destination state, "including exploitative and insecure working conditions, poverty, sexual harassment, inaccessible health services, harassment by immigration authorities, and inhumane treatment in detention centers" (Basok and Piper 2012: 47).

Despite similar elements of coercion and deception used against both smuggled and trafficked persons, these crimes are categorized differently; for instance, states are permitted to use enforcement measures against smuggled persons, whose rights protections are more limited than trafficked persons (Obokata 2005b: 397-8). The result is a problematic response to this disparity in legal categorization. Joseph Lelliott argues that smuggled unaccompanied minors are denied the greater protections afforded to trafficking victims (2017: 252), contrary to the best interests of the child principle (2017: 267). On the other hand, if a state views only traffickers as those responsible for the abuse of migrants, without also considering this abuse "a by-product of exploitive employment practices, restrictive immigration policies, and vast economic disparities between rich and poor countries," Tanya Basok and Nicola Piper (2012: 43) (among others) suggest that the criminalized narrative of human trafficking may conceal the economic motivations of a trafficked person, or conceal the fact that destination states benefit economically from exploited labour (2012: 43). ${ }^{\mathrm{xxv}}$ Lastly, human trafficking should be viewed not only as a criminal justice issue, but also as a subset of illegal and involuntary migration "that characterizes recent international migration patterns" (Mcsherry and Cullen 2007: 218-219).

The criminal activity surrounding human trafficking can also intersect with other human rights violations, heightened in situations of armed conflict and displacement, such as the recruitment and use of children in armed violence (UNODC 2018: 12). In addition, human trafficking may be viewed as a threat to national security as it is in the US, for its potential to spread communicable diseases and establish criminal enterprises, which destabilize other countries, fund terrorist groups, and smuggle illicit goods into the country (Fish 2017: 547). ${ }^{\text {xxvi }}$ 


\section{Human rights and business}

Second, "more robust regulations and inspection of labour practices have been recommended in order to enhance the protection of labour rights" in attempt to prevent forced labour (Obokata 2019: 36). Many countries have regimes to hold private sector multinational actors accountable for their role in maintaining environments conducive to trafficking and other forms of forced labour. Canada, for instance, is expected to join others like the UK, Australia, France, Norway, and the Netherlands, in passing legislation that improves transparency in business and industry supply chains by requiring more rigorous reporting. ${ }^{\text {xxxvii }}$ Further, European Union legislation necessitating corporate human rights and environmental due diligence is expected in 2021. ${ }^{\text {xxxviii }}$

These laws reflect the criminal liability for corporations (and individuals acting on their behalf) established under UNTOC (Jha 2018: 239; UNTOC 2000: art 10). These laws also reflect the nonlegally binding 2017 UN General Assembly's Call to Action to End Forced Labour, Modern Slavery and Human Trafficking. ${ }^{x x i x}$ Indeed, codes of conduct of multi-national corporations, which uphold relevant labour standards, should be regarded as "part of the overall principles for preventing and suppressing organized crime and human trafficking" (Obokata 2010: 128).

\section{Conclusion}

This chapter has endeavoured to explore the major points of interface between the law on the suppression of TOC and the international law of human rights. What seems clear is that, despite the resistance of prosecutorial and policing authorities around the world, those points of interface are increasing steadily. This is due in no small part to the increasing recognition of layered human rights concerns vis-à-vis the victims of TOC operations and resultant energy being focused on protecting those rights and redressing their violation. The pervasive issue of human trafficking is a timely case study of this intersection of obligations. What remains to be seen is whether these trends will remain an application of human rights-flavoured victimology, or whether concern for the protection of the procedural rights of the accused will see a corresponding increase. 
Reference Materials

Basok, T. and Piper, N. (2012) "Management Versus Rights: Women's Migration and Global Governance in Latin America and the Caribbean" Feminist Economics 18(2) pp. 35-61.

Boily v. Canada (2011), Comm No. 327/2007, UN Doc CAT/C/47/D/327/2007. Available at: < http://www.worldcourts.com/cat/eng/decisions/2011.11.14_Boily_v_Canada.pdf>

Bassiouni, M.C. (1974) 'An appraisal of the growth and developing trends of international criminal law', Revue International de Droit Penal 45, pp. 405-433.

Boister, N.(2018) An Introduction to Transnational Criminal Law. 2nd ed. Oxford: Oxford University Press.

Boister, N. (2002) "Human Rights Protection in the Suppression Conventions", Human Rights Law Review, 2(2), pp. 199-227.

Canadian Charter of Rights and Freedoms, s 7, Part I of the Constitution Act, 1982, being Schedule B to the Canada Act 1982 (UK), 1982, c 11.

Case of Siliadin v France (Merit and Just Satisfaction), (2006) ECtHR App No. 73316/01.

Case of Trufin v Romania (Merit and Just Satisfaction) (2009), ECtHR App No. 3990/04.

Council of Europe (1950) European Convention for the Protection of Human Rights and Fundamental Freedoms, as amended by Protocols Nos. 11 and 14, 4 November 1950, ETS No 5 (entered into force 3 September 1953) [ECHR].

(2005) Council of Europe Convention on Action against Trafficking in Human Beings, 16 May 2005, ETS No 197 (entered into force 1 February 2008), Available at: <https://rm.coe.int/168008371d >

Currie, R. J. (2000) “Human Rights and International Mutual Legal Assistance: Resolving the Tension” Criminal Law Forum 11 (2) pp. 143-181.

(2015) "The Protection of Human Rights in Transnational Criminal Law" in Boister, N. \& Currie, R.J. (eds) Routledge Handbook of Transnational Criminal Law. Abingdon: Routledge.

(2019) "Extradition Scrap: Netherlands Court Bars Extradition Over UK Prison Conditions" on International \& Transnational Criminal Law (blog), 19 May, online: rjcurrie.typepad.com/internationaland-transna/2019/05/extradition-scrap-netherlands-court-bars-extradition-over-uk-prison-conditions.html

Currie, R. J. \& Rikhof, J. (2020) International \& Transnational Criminal Law. 3rd ed. Toronto: Irwin Publishing.

European Union (2012), Charter of Fundamental Rights of the European Union, 26 October 2012, 2012/C 326/02. Available at: 〈https://eur-lex.europa.eu/legal-content/EN/TXT/PDF/?uri=CELEX:12012P/TXT\&from=EN>

Fish, C. (2017) "Extraterritorial Human Trafficking Prosecutions: Eliminating Zones of Impunity within the Limits of International Law and Due Process" St John's Law Review 91(2), pp. 529 - 557.

Harfield, C. (2012) 'Human Rights and the Policing of Transnational Organized Crime' in Allum, F. \& Gilmore, S. (eds) Routledge Handbook of Transnational Organized Crime. Abingdon: Routledge.

International Labour Office (2014) Profits and Poverty: The Economics of Forced Labour. Geneva. Available: <https://www.ilo.org/wcmsp5/groups/public/---ed_norm/---declaration/documents/publication/wcms_243391.pdf >

(2017) Global Estimates of Modern Slavery: Forced Labour and Forced Marriage. Geneva. Available: < https://www.ilo.org/wcmsp5/groups/public/---dgreports/---

dcomm/documents/publication/wcms 575479.pdf> 
International Labour Organization (2007) Convention concerning the Prohibition and Immediate Action for the Elimination of the Worst Forms of Child Labour (No. 182), 17 Jun 1999, 87th ILC Sess (entered into force 19 Nov 2000), Available at:

<https://www.ilo.org/dyn/normlex/en/f?p=NORMLEXPUB:12100:0::NO:12100:P12100_INSTRUMENT_ID:3123 27:NO>

Jha, A. (2018) "The Law on Trafficking in Persons: the Quest for an Effective Model” Asian Journal of International Law 8 (1) pp. 225-257.

Johnston, J. (2011) "The Use of Torture as a Basis for Refusing Extradition and the Use of Diplomatic Assurances" International Criminal Law Review 11(1) pp. 1-48.

Lavrysen, L. \& Mavronicola, N. (eds) (2020) Coercive Human Rights: Positive Duties to Mobilize the Criminal Law Under the ECHR. Oxford: Hart Publishing.

League of Arab States (2004) Arab Charter on Human Rights, 22 May 2004, entered into force 15 March 2008 [ACHR].

(2012) Arab Convention on Combating Transnational Organized Crime. Available at: < http://haqqi.info/en/haqqi/legislation/arab-convention-against-transnational-organized-crime>

Lelliott, J. (2017) "Smuggled and Trafficked Unaccompanied Minors: Towards a Coherent, Protection-Based Approach in International Law” International Journal of Refugee Law 29 (2) pp. 238-269.

Manuel Garcia Franco v Ecuador (1997) Case 10.258, Inter-Am CHR No. 1/97. Available at: < http://www.worldcourts.com/iacmhr/eng/decisions/1997.03.12_Garcia_Franco_v_Ecuador.pdf >

Mcsherry, B. and Cullen, M. (2007) “The Criminal Justice Response to Trafficking in Persons: Practical Problems with Enforcement in the Asia-Pacific Region” Global Change, Peace and Security 19(3) pp. 205-220.

Noortmann, M. and Sedman, D. (2016) “Transnational Criminal Organisations and Human Rights” in Hauck, P. \& Peterke, S. (eds) International Law and Transnational Organised Crime. Oxford: Oxford University Press, pp. 406421.

Obokata, T. (2005a) "Trafficking of Human Beings as a Crime against Humanity: Some Implications for the International Legal System” International \& Comparative Law Quarterly, 54(2) pp. 445-458.

(2005b) "Smuggling of Human Beings from a Human Rights Perspective: Obligations of Non-State and State Actors under International Human Rights Law” International Journal of Refugee Law 17(2) pp. 394 415 .

(2006a) "Trafficking of Human Beings as a Human Rights Violation: Obligations and Accountability of States" in Obokata, T. (ed) Trafficking of Human Beings from a Human Rights Perspective: Towards a Holistic Approach. Leiden: Martinus Nijhoff Publishers, pp. 147-172.

(2006b) "Understanding Trafficking" in Obokata, T. (ed) Trafficking of Human Beings from a Human Rights Perspective: Towards a Holistic Approach. Leiden: Martinus Nijhoff Publishers, pp. 9-37.

(2006c) "National Case Studies on Trafficking of Human Beings in Thailand, Poland, and the United Kingdom" in Obokata, T. Trafficking of Human Beings from a Human Rights Perspective: Towards a Holistic Approach (Leiden: Martinus Nijhoff Publishers, pp. 39-83.

(2010) "Global Governance and International Migration: A Case Study of Trafficking of Human Beings" Refugee Survey Quarterly 29(1), pp. 120-136. 
(2015) "Human trafficking" in Boister, N. \& Currie, R. J. (eds), Routledge Handbook of Transnational Criminal Law. New York: Routledge, pp. $171-187$.

(2017) "The Value of International Law in Combating Transnational Organized Crime in the Asia-Pacific" Asian Journal of International Law 7(1) pp. 39-60.

(2019) "Combating Transnational Organised Crime through International Human Rights Law" International Human Rights Law Review 8(1), pp.1-37.

Orejuela v Colombia (2002) HRC, $75^{\text {th }}$ Session (23 July 2002), UN Doc No CCPR/C/75/D/848/1999, Available at: http://www.worldcourts.com/hrc/eng/decisions/2002.07.23_Rodriguez_Orejuela_v_Colombia.htm

Organization of African Unity (OAU) (1981) African Charter on Human and Peoples' Rights, 27 June 1981, CAB.LEG/67/3 rev. 5, 21 ILM 58 (1982) (entered into force 21 October 1986) [ACHPR].

Organization of American States (OAS) (1969) American Convention on Human Rights. 22 November 1969 (entered into force 18 July 1978). [AmCHR].

(1994) Inter-American Convention on International Traffic in Minors, 18 March 1994, OAS No. 79 (entered into force 15 August 1997).

Podeschi v San Marino (2017) ECtHR App no. 66357/14

R. v. Lindsay, 2009 ONCA 532. Available at: < https://sherloc.unodc.org/cld/uploads/res/case-lawdoc/criminalgroupcrimetype/can/2009/r_ v _ lindsay html/R_v_Lindsay_2009_ONCA_532.pdf>

R. v. Terezakis, 2007 BCCA 384. Available at: < https://sherloc.unodc.org/cld/case-lawdoc/drugcrimetype/can/2007/r_v_terezakis_2007_bcca_384_html?Ing=en\&tmpl=sherloc >

Satterthwaite, M. (2013) "The legal regime governing transfer of persons in the fight against terrorism" in van den Herik, L. \& Schrijver, N. (eds) Counter-Terrorism Strategies in a Fragmented International Legal Order: Meeting the Challenges. Cambridge: Cambridge University Press, pp. 589-638.

Soering v United Kingdom (1989) ECtHR App No. 14038/88, Series A, No. 161.

South Asian Association for Regional Co-operation (SAARC) (2002), Convention on Preventing and Combatting Trafficking in Women and Children for Prostitution. Available at: $\lfloor$ http://un-act.org/wpcontent/uploads/2015/11/South-Asian-Association-for-Regional-Cooperation-SAARC-Convention-on-Preventingand-Combating-Trafficking-in-Women-and-Children-for-Prostitution.pdf>

Vasek, K. \& Alston, P. (eds) (1982) The International Dimensions of Human Rights. Connecticut: Greenwood Press.

Velasquez-Rodriguez $v$ Honduras (1988) IACrtHR (Ser. C) No. 4. Available at: <https://www.refworld.org/cases,IACRTHR,40279a9e4.html>

United Kingdom Human Rights Act 1998 (UK) 9 November 1988, c 42.

United States Department of State (2018) Trafficking in Persons Report June 2018. Available at: 〈https://www.state.gov/wp-content/uploads/2019/01/282798.pdf>

(2019) Trafficking in Persons Report June 2019. Available at: <https://www.state.gov/wpcontent/uploads/2019/06/2019-Trafficking-in-Persons-Report.pdf $>$

United States v Burns, 2001 SCC 7, 1 SCR 283.

\section{United Nations:}


- (1948) Universal Declaration of Human Rights, GA Res 217A (III), UNGAOR, $3^{\text {rd }}$ Sess, Supp No 13, UN Doc A/810 (1948) 71.

- (1966) International Covenant on Civil and Political Rights, 16 December 1966, 999 UNTS 171 (entered into force 23 March 1976) [ICCPR].

- (1966) International Covenant on Economic, Social and Cultural Rights, 16 December 1966, 999 UNTS 3 (entered into force 3 January 1976) [ICESCR].

- (1979) Convention on the Elimination of All Forms of Discrimination Against Women, 18 December 1979, 1249 UNTS 13 (entered into force 3 September 1981) [CEDAW].

- (1984) Convention Against Torture and Other Cruel, Inhuman or Degrading Treatment or Punishment, 10 December 1984, 1465 UNTS 85 (entered into force 26 June 1987) [UNCAT].

- (1988) Convention Against Illicit Traffic in Narcotics Drugs and Psychotropic Substances, 20 December 1988, 1582 UNTS 95 (entered into force 11 November 1990) [Vienna Narcotics Convention].

- (1989) Convention on the Rights of the Child, 20 November 1989, 1577 UNTS 3 (entered into force 2 September 1990) [CRC].

- (1993) Vienna Declaration and Programme of Action, UNGAOR, 19 July 1993, UN Doc A/CONF.157/23, Available at: 〈https://undocs.org/en/A/CONF.157/23>

- (2000) Optional Protocol to the Convention on the Rights of the Child on the sale of children, child prostitution and child pornography, 25 May 2000, 2171 UNTS 277 (entered into force 18 January 2002) [CRC OPSC].

- (2000) Convention on Transnational Organized Crime, 15 November 2000, 2225 UNTS 209 (entered into force: 29 September 2003) [UNTOC].

- (2000) Protocol to Prevent, Suppress and Punish Trafficking in Persons, especially Women and Children, supplementing the United Nations Convention against Transnational Organized Crime, 14 Dec 2000, 2237 UNTS 319 (entered into force 25 December 2003) [Human Trafficking Protocol].

- (2002) Report of the United Nations High Commissioner for Human Rights to the Economic and Social Council: "Recommended Principles and Guidelines on Human Rights and Human Trafficking", UNECSCOR, 2002, UN Doc E/2002/68/Add.1. Available at: 〈https://undocs.org/en/E/2002/68/Add.1>

- (2004) Report of the Conference of the Parties to the United Nations Convention Against TOC on its First Session, held in Vienna from June 28 - July 8 2004. UNCTOC, $1^{\text {st }}$ Sess, UN Doc CTOC/COP/2004/6 (2004). Available at: $\lfloor\underline{\text { https://undocs.org/CTOC/COP/2004/6 }>}$

- (2005) Basic Principles and Guidelines on the Right to a Remedy and Reparation for Victims of Gross Violations of International Human Rights Law and Serious Violations of International Humanitarian Law, GA Res 60/147, UNGAOR, 60 ${ }^{\text {th }}$ Sess, UN Doc A/RES/60/147.

- (2010) Global Plan of Action Combatting Trafficking in Persons, GA Res 64/293, UNGAOR, 64 ${ }^{\text {th }}$ Sess, UN Doc A/RES/64/293. Available at: <https://www.unodc.org/documents/humantrafficking/United_Nations_Global_Plan_of_Action_to_Combat_Trafficking_in_Persons.pdf > 
- (2011) Concluding observations of the Human Rights Committee: Ethiopia, UNHRC, $102^{\text {nd }}$ Sess, 2011, UN Doc CCPR/C/ETH/CO/1. Available at: <https://www.icj.org/wp-content/uploads/2011/08/ConcludingObservations-CCPR-Ethiopia-2011-eng.pdf>

- (2015) Transforming our world: the 2030 Agenda for Sustainable Development, GA Res 70/01, UNGAOR, 70th Sess, UN Doc A/RES/70/1. Available at: <www.un.org/ga/search/view_doc.asp?symbol=A/RES/70/1\&Lang=E $>$.

- (2017) Joint report of the Special Rapporteur on the sale and sexual exploitation of children, including child prostitution, child pornography and other child sexual abuse material and the Special Rapporteur on trafficking in persons, especially women and children. UNGAOR, 72 ${ }^{\text {nd }}$ Sess, UN Doc A/72/164 (2017), Available at: 〈https://undocs.org/A/72/164>

- (2017) Political declaration on the implementation of the United Nations Global Plan of Action to Combat Trafficking in Persons, UNGAOR, $72^{\text {nd }}$ Sess, UN Doc A/72/1 (2017). Available at: $<$ https://undocs.org/pdf?symbol=en/a/res/72/1>

- (2018) Commission on Crime Prevention and Criminal Justice, Report on the twenty-seventh session, UNESCOR, 2018, Supp No. 10, UN Doc E/CN.15/2018/15. [CCPCJ Report]. Available at: $<$ https://www.unodc.org/documents/commissions/CCPCJ/CCPCJ_Sessions/CCPCJ_27/1803810E_18June 2018_Advance_version.pdf>

- (2018) United Nations Office on Drugs and Crime, Global Report on Trafficking in Persons 2018. Vienna: United Nations. Available at: <www.unodc.org/documents/data-andanalysis/glotip/2018/GLOTiP_2018_BOOK_web_small.pdf> [UNODC]

- United Nations Office of the High Commission on Human Rights, "Committee Against Torture", online: <www.ohchr.org/EN/HRBodies/CAT/Pages/catindex.aspx >

- United Nations Office of the High Commission on Human Rights, "Working Group on Arbitrary Detention", online:< www.ohchr.org/EN/Issues/Detention/Pages/WGADIndex.aspx >

\section{Endnotes}

\footnotetext{
* We are grateful to Laura Ellyson for research assistance, and to Grace Levy and Olivia Genge for editorial assistance.

${ }^{i}$ And sometimes groups, but we will not engage in the debate around "collective" human rights here.

${ }^{i i}$ For a brief but effective historical overview, see Saunders, P. M. \& Currie, R. J. (eds) (2019), Kindred's International Law: Chiefly as Interpreted and Applied in Canada, 9th ed, Toronto: Emond, pp. 634-37.

iii Also of note is the 2012 ASEAN Human Rights Declaration, which like the UDHR is not a binding instrument but rather a statement of principles. Online: asean.org/asean-human-rights-declaration/

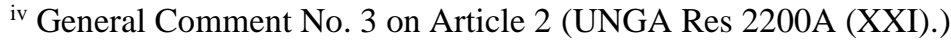

${ }^{\mathrm{v}}$ The formal legal surrender between states of individuals wanted on criminal charges or to serve a criminal sentence.

${ }^{\text {vi }}$ The mutual obtainment and provision of evidence between states for use in criminal proceedings.

vii The United Nations Office on Drugs and Crime (UNODC) has published model treaties on extradition and mutual legal assistance which suggest treaty provisions that would protect human rights. For the most recent version see UNODC, Revised Manuals on the Model Treaty on Extradition and the Model Treaty on Mutual Assistance in Criminal Matters (undated), online: https://www.unodc.org/pdf/model_treaty_extradition_revised_manual.pdf ${ }^{\text {viii }}$ E.g. article 3 of the UNCAT, which prohibits individuals from being transferred to states in which they will face torture.
} 
${ }^{\text {ix }}$ See also the decision of the Supreme Court of the Netherlands in The Netherlands v. Short, reprinted in (1990), 29 I.L.M. 1375.

${ }^{x}$ Some examples as regards Canada, normally regarded as a human rights-friendly state: $N g$ v. Canada (1993), Comm. No. 469/1991, UN Doc CCPR/C/49/D/469/1991, at para. 14.2; Cox v. Canada (1994), Comm. No. 539/1993, UN Doc CCPR/C/52/D/539/1993; Kindler v. Canada (1993), Comm. No. 470/1991, UN Doc CCPR/C/48/D/470/1991; Judge v. Canada (2003), Comm. No. 829/1998, UN Doc. CCPR/C/78/D/829/1998.

${ }^{x i}$ For useful background, see UNODC, UNODC and the Promotion and Protection of Human Rights: Position Paper (2012).

${ }^{x i i}$ As examples, extrajudicial killings of drug lords breach the right to life; maritime piracy raises concerns of liberty and security; and, forced labour impacts one's right to work in favourable conditions. For a discussion on various civil, economic, social and cultural rights and transnational organized crime, see Obokata 2019.

xiii ICESCR arts 12 and 15. As examples, the unfulfillment of harm reduction measures around illicit drug use engages health, and the illegal trafficking of cultural property or wildlife may breach cultural rights.

xiv These obligations have been re-affirmed in various international instruments, including the 2005 resolution, Basic Principles and Guidelines on the Right to a Remedy and Reparation for Victims of Gross Violations of International Human Rights Law and Serious Violations of International Humanitarian Law, UNGA Res 60/147, Dec/05, online: <https://www.ohchr.org/en/professionalinterest/pages/remedyandreparation.aspx >, [Res 60/147], art III, paras 4 and 5 , which recites that states must cooperate with others in the pursuit of international justice.

${ }^{x v}$ As at December 2020, 117 States are signatories and 117 are parties to the Protocol.

xvi Under art 3(d), a child is anyone under eighteen years of age.

xvii Between 2009 and 2018, the number of States employing an institution to systematically collect and disseminate data on trafficking cases increased from 26 to 65 .

xviii The Council of Europe Convention on Action against Human Trafficking aims to prevent trafficking, protect victims' human rights, and promote international co-operation on suppression (art 1).

xix [SAARC Convention], promoting co-operation on prevention and suppression of sex trafficking of women and children, and the repatriation and rehabilitation of victims (art II).

${ }^{\mathrm{xx}}$ [Inter-American Convention], aiming to protect the fundamental human rights of minors by preventing and punishing international trafficking of minors (art 1).

xxi [Arab Convention] at arts 11 and 12, requiring States to enact criminal provisions prohibiting acts by organized criminal groups, including human trafficking and trafficking in human organs.

xxii [CRC], arts 3(1), 3(2), 6(2), and 11(1), ensuring the best interests of the child are paramount as well as the protection of their well-being, survival and development; further, ensuring that States take measures to prevent a child's illicit transfer.

xxiii [ACHPR], ensuring freedom from all forms of exploitation and slavery, and inhuman or degrading punishment (art 5).

xxiv [AmCHR], which prohibits trafficking of women, involuntary servitude and slavery, and forced or compulsory labour (art 6).

${ }^{\mathrm{xxv}}$ [ArCHR], prohibiting forced labour and human trafficking for sexual or other forms of exploitation (art 10).

xxvi [ECFR] prohibiting human trafficking, forced labour and slavery/servitude (art 5).

xxvii For instance, UK initiatives have contributed to numerous arrests in the UK, Australia, Germany and Hong

Kong, and cooperation in the Balkans gathered intelligence on Turkish and Kosovan gangs trafficking thousands of people. Obokata 2006 III, supra note 89, at 72-3.

xxviii Article 23 ensures an effective remedy for those whose rights have been violated.

${ }^{\text {xxix }}$ Res $27 / 2$ "Preventing and combating trafficking in persons facilitated by the criminal misuse of information and communications technologies" and Res 27/3, "Improving the protection of children against trafficking in persons, including by addressing the criminal misuse of information and communications technologies".

${ }^{x x x}$ Though, some authors suggest this Protocol "focuses on the criminal aspects of cross-border migration and is more concerned with national security and border control than the rights-based protection of trafficked victims." (Basok and Piper 2012: 42).

xxxi The ECtHR found that Greece was in breach of ECHR Article 4(2), which prohibits forced or compulsory labour.

xxxii For Obokata's complete argument, see Obokata 2005.

xxxiii For more discussion, see Noortmann \& Sedman (2016).

xxxiv Many anticipate the COVID-19 pandemic will significantly increase demand for smugglers due to unprecedented border closures and exacerbated vulnerabilities. States are encouraged to craft measures in response to the pandemic to fulfil their human rights obligations, including strengthening efforts to identify and support 
trafficking and exploitation victims; for example: Women's Link Worldwide, Amnesty International, and International Planned Parenthood Federation, Guidelines for African States to protect the rights of women and girls during the COVID-19 pandemic (2020), online: <https://bit.ly/3qcLrud>.

xxxv Basok \& Piper, citing Jacqueline Berman, 2010.

xxxvi Fish 2017at 547, citing the United States Court of Appeals, Eleventh Circuit decision of 24 March 2016 in the case of United States v Baston, wherein the United States exercised extraterritorial jurisdiction over a Jamaican national for his trafficking of women worldwide; in 2014, he was found guilty of 21 counts of sex trafficking and money laundering. For more, see: 〈https://bit.ly/39vLtYu>.

xxxvii Canada's Senate most recently introduced Bill S-216, the Modern Slavery Act, (second reading 5 Nov 2020), online: 〈https://www.parl.ca/LegisInfo/BillDetails.aspx?Language=E\&billId=10922230\&View=0 >, which would require large Canadian businesses to file annual, public reports regarding their steps to "prevent and reduce the risk that forced or child labour is used in any step in the production of goods [...] The Act also provides for an inspection regime." Fasken Martineau DuMoulin LLP, "Slavery in the Supply Chain: New Canadian Rules on the Way?" (24 November 2020), online (blog): <https://www.fasken.com/en/knowledge/2020/11/24-slavery-in-the-supply-chainnew-canadian-rules-on-the-way/>. These legislative efforts complement a shifting focus toward accountability of multi-national actors in Canadian jurisprudence. In February 2020, the Supreme Court of Canada in Nevsun Resources Ltd v Araya, 2020 SCC 5, online: 〈https://decisions.scc-csc.ca/scc-csc/scc-csc/en/item/18169/index.do〉, ruled that a 2014 class action by three Eritreans against Canada-based Nevsun Resources can proceed on the basis that international norms apply to a claim of forced labour, inter alia, at a mine operated by Nevsun's subcontractor (a company owned by the Eritrean government); in so doing, the Court rejected the defendant's argument that domestic courts are precluded from assessing the acts of a foreign government.

xxxviii See: <https://www.euractiv.com/section/global-europe/news/new-human-rights-laws-in-2021-promises-eujustice-chief/>. Some groups have recommended what such legislation should include; for instance, Human Rights Watch, online: <https://www.hrw.org/news/2020/06/24/recommendations-new-eu-legislation-mandatory-humanrights-and-environmental-due $>$. xxxix “Call to Action to End Forced Labour, Modern Slavery and Human Trafficking," online: <https://bit.ly/31sX9gB >, which aims to achieve SDG target 8.7. 